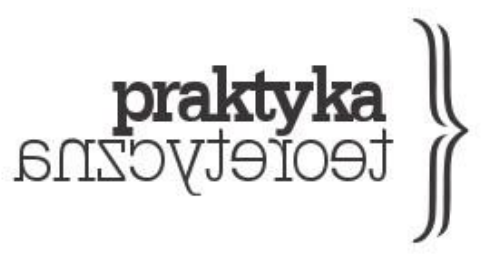

ISSN 2081-8130

DOI: $10.14746 /$ prt.2017.2.1 www.praktykateoretyczna.pl

\title{
AlTERNATYWY DLA DOCHODU PODSTAWOWEGO: PRZEGLĄD KRYTYCZNY*
}

\section{GUY STANDING}

PRZEŁOŻYŁ: TOMASZ PŁOMIŃSKI

\begin{abstract}
Abstrakt: Rozdział książki Guya Standinga „Basic Income: And How Can We Make It Happen”. Autor analizuje szereg rozwiązań będących odpowiedzią na kryzysy gospodarcze, nierówności i ubóstwo: płacę minimalna, składkowe ubezpieczenia społeczne, pomoc społeczną opartą na kryterium dochodowym, dotowanie żywności, ulgi podatkowe, programy workfare i gwarancje zatrudnienia. Ocenia te rozwiązania w odniesieniu do zasad sprawiedliwości społecznej i porównuje z dochodem podstawowym.
\end{abstract}

Słowa kluczowe: dochód podstawowy, gwarancja zatrudnienia, sprawiedliwość społeczna, ubezpieczenie społeczne, workfare

\footnotetext{
* Prezentowany tekst jest przekładem 9 rozdziału książki Guya Standinga Basic Income: And How We Can Make It Happen. Tytuł pochodzi od redakcji, śródtytuły pochodzą od autora.
} 
Jakie są główne alternatywy wobec dochodu podstawowego proponowane lub implementowane w celu przeciwdziałania obecnym kryzysom ekonomicznej niepewności, nierówności i ubóstwa? Ten rozdział omawia następujące propozycje: krajową pensję minimalną i jej odmianę, „godziwą płacę” (living wage); składkowe ubezpieczenia społeczne (narodowe ubezpieczenie społeczne w Wielkiej Brytanii); pomoc społeczną oparta na kryterium dochodowym; dotowanie żywności i innych dóbr podstawowych, włączając w to bony żywnościowe; programy workfare $\mathrm{i}$ wersje zasiłku zależnego od pracy; oraz ulgi podatkowe, razem z aktualnie wprowadzaną w Wielkiej Brytanii ulgą o niefortunnej nazwie „powszechny kredyt” („Universal Credit’). Każde z tych rozwiązań wymieniano jako lepsze od dochodu podstawowego i wszystkie $z$ nich są obecnie wykorzystywane w praktyce przez rozwinięte gospodarki na całym świecie.

Uczciwe porównanie wymaga ich oceny według jednakowych kryteriów. W każdym przypadku należy zadać następujące pytania: czy dana polityka służy sprawiedliwości społecznej ${ }^{1}$ ? Czy oferuje sposób na zwiększenie wolności w republikańskim sensie, czy też ją narusza2? Czy zmniejsza nierówności, czy może je zwiększa3? Rozszerza bezpieczeństwo socjoekonomiczne, czy pogłębia jego brak? Czy istotnie zmniejsza ubóstwo? Wszystkie z tych pytań powinny zostać rozważone w kontekście globalizacji, rewolucji technicznej i neoliberalnej polityki ekonomicznej kształtującej światową gospodarkę rynkowa.

Zasady sprawiedliwości społecznej określone w poprzednich rozdziałach wyznaczaja przydatną listę do oceny każdej z polityk. Przypomnijmy:

- Zasada różnicy w wymiarze bezpieczeństwa - polityka jest sprawiedliwa społecznie tylko pod warunkiem, że zwiększa bezpieczeństwo najmniej zabezpieczonych grup społecznych.

- Zasada antypaternalistyczna - polityka jest sprawiedliwa społecznie tylko pod warunkiem, że nie narzuca wybranym grupom społecznym formy kontroli, której nie narzuca również większości wolnych grup w społeczeństwie.

- Zasada praw przed dobroczynnościa - polityka jest sprawiedliwa społecznie tylko pod warunkiem, że poszerza prawa odbiorców świadczeń lub usług i ogranicza swobodę decyzji jej dostarczycieli.

\footnotetext{
${ }^{1}$ Po używane przez Standinga kryteria sprawiedliwości społecznej, zob. rozdział 2 jego książki. W skrócie: sprawiedliwość społeczna odnosi się do możliwie równego i pozbawionego dyskryminacji udziału w wytwarzanym społecznie oraz w naturalnym bogactwie. Zob. też zasady sprawiedliwości społecznej dalej w tekście (przyp. red.).

2 Definicji republikańskiej wolności poświęcony jest rozdział 3 książki Standinga, w którym autor przytacza tradycyjną, Arystotelesowską definicję wolności w sensie republikańskim jako wolności od dominacji, zarówno tej aktualnej, jak i tej potencjalnej (przyp. red.).

${ }^{3}$ Szerokie rozumienie nierówności Standing omawia w rozdziale 4. Nierówności nie rozumie wyłącznie jako nierówności w ściśle ekonomicznym sensie, ale także jako nierówność bezpieczeństwa i poczucia pewności (przyp. red.).
} 
Można do nich dodać dwie kolejne (Standing 2016):

- Zasada ograniczenia ekologicznego - polityka jest sprawiedliwa społecznie tylko pod warunkiem, że nie obciąża kosztem ekologicznym społeczności lub bezpośrednio nią dotkniętych.

- Zasada godnej pracy - polityka jest sprawiedliwa społecznie tylko pod warunkiem, że nie utrudnia ludziom wykonywania pracy w godny sposób i nie ogranicza w tym najbardziej narażonych grup.

Każda z polityk powinna zostać oceniona zgodnie z tymi zasadami. W niektórych przypadkach będą się oczywiście pojawiać między nimi konflikty, powinniśmy jednak być ostrożni wobec każdej polityki, która znacząco je narusza.

\section{Ustawowa płaca minimalna i „godziwa płaca”}

Niemal wszystkie rządy w erze globalizacji osłabiały negocjacje zbiorowe i ograniczały funkcjonowanie związków zawodowych w ramach swoich planów uelastyczniania rynków pracy. Większość z nich łączyła to z dolnymi pułapami płacowymi, wprowadzając krajowe ustawowe płace minimalne, tak jak w Wielkiej Brytanii i, ostatnio, w Niemczech, lub kładąc większy nacisk na istniejące regulacje płacy minimalnej, tak jak Stany Zjednoczone, nawet jeśli pozwalano na spadek rzeczywistej wartości płacy.

Paradoksalnie, ustawowa pensja minimalna ma największą szansę funkcjonować poprawnie na rynku pracy w sektorze przemysłowym, gdzie dominuje stabilne pełnoetatowe zatrudnienie. Ma ona mniejszą szansę funkcjonować zgodzie z założeniami w systemie elastycznej, usługowej pracy, w którym pomiar pracy jest często utrudniony, o ile w ogóle możliwy. Pensje minimalne są zazwyczaj ustalane w skali godzinowej. W jaki sposób jednak, na przykład, zmierzyć „godzinę pracy” w gospodarce usługowej, w której ludzie nie odbijają czasu wejścia i wyjścia w stałym miejscu pracy, a coraz częściej pracują o różnych porach i w wielu miejscach? Poza tym płaca minimalna, w przeciwieństwie do dochodu podstawowego nie wzmacnia pozycji negocjacyjnej robotników. Jeśli masz jakiś punkt podparcia, łatwiej ci powiedzieć „nie” nieuczciwej propozycji wynagrodzenia, niezależnie od tego, czy jest ona wyższa od płacy minimalnej. Jeśli nie dysponujesz dochodem podstawowym i nie podoba ci się oferowana płaca, pracodawca może po prostu powiedzieć „to twój problem”.

Wprowadzanie płacy minimalnej, a następnie nadzór, czy jest ona stosowana, jest jednocześnie skomplikowane i kosztowne. Od czasu brytyjskiej Ustawy o minimalnym wynagrodzeniu z 1998 roku tylko dziewięć spośród setek łamiących prawo firm zostało oskarżonych o niewypłacanie należnej pensji. Ci, którzy nie reaguja na imienne wskazywanie sprawców, muszą być ścigani na drodze długotrwałych postępowań sądowych. Dodatkowo 
płace minimalne zabezpieczaja jedynie zatrudnionych, ignorując pozbawionych pracy, a także rosnąca liczbę samozatrudnionych i tak zwanych niezależnych podwykonawców, których spotykamy teraz we wszystkich uprzemysłowionych krajach. Nie sa także efektywnym sposobem na walkę z ubóstwem, ponieważ, przynajmniej w Wielkiej Brytanii, większość ludzi otrzymujących płacę minimalną nie żyje w najbiedniejszych gospodarstwach domowych.

Przeciwnicy pensji minimalnej lub ci, którzy uważają jej poziom za „zbyt wysoki”, zazwyczaj twierdza, że powoduje ona ograniczenie zatrudnienia przez firmy w celu oszczędzenia na wypłacanych pensjach. W rzeczywistości istnieją dowody na niski wpływ płacy minimalnej na poziom bezrobocia. Pracodawcy jednak i tak tna koszty na inne sposoby, które moga pozostawić robotników w niewiele lepszej, lub nawet gorszej sytuacji.

Załóżmy przykładowo, że przy minimalnej godzinowej pensji w wysokości 10 funtów firma oferująca usługi sprzątania zatrudni 100 robotników w wymiarze trzydziestu godzin tygodniowo. Jeśli płaca minimalna zostałaby podniesiona do 12 funtów, to firma obcięłaby liczbę godzin do 25 , pozostawiając koszty płacowe na tym samym poziomie bez żadnego zysku dla robotników (prawdopodobnie wyszliby oni na tym gorzej, ponieważ musieliby wykonać tę samą ilość pracy w krótszym czasie lub odrabiać nieopłacone nadgodziny).

Dokładnie to stało się po wprowadzeniu przez rząd brytyjski krajowej godziwej płacy (National Living Wage) w 2015 roku (Lawrence 2016). W jednym z przypadków firma oferująca usługi sprzątania urzędowi skarbowemu obcięła tygodniową liczbę godzin dla sprzatających poniżej 30, wpędzając swoich robotników w okrutną pułapkę ubóstwa; oprócz mniejszej liczby płatnych godzin, która zniwelowała podwyżkę stawki godzinowej, stracili uprawnienie do ulg podatkowych przysługujących tylko ludziom pracującym co najmniej trzydzieści godzin tygodniowo. Sprzątający stracili na tym tak wiele, że niektórzy z nich dowiedzieli się, że więcej pieniędzy otrzymaliby rzucając pracę i zgłaszając się po pełny zasiłek.

Inny przykład krzywdy wyrządzanej przez złożone systemy pomocy społecznej: pewna kobieta, która straciła ulgi podatkowe, została zmuszona do pozostania w pracy, ponieważ ubiegając się o zasiłki z pomocy społecznej, prawie na pewno utraciłaby swój rodzinny dom. Jako że wciąż mieszkała w domu z trzema sypialniami, w którym dorastały jej dzieci, tak zwany „podatek od sypialni” („Bedroom tax”) zmniejszajacy zasiłek mieszkaniowy ludziom posiadającym rzekomo więcej niż konieczną liczbę sypialni dla najbliższej rodziny pozbawiłby ją moźliwości opłacania czynszu i zmusił do przeprowadzki do mniejszego mieszkania. Nie dziwi więc fakt, że krótko po tym została przyjęta do szpitala z wysokim ciśnieniem wynikającym ze stresu.

Jeśli chodzi o zasady sprawiedliwości społecznej, to płace minimalne nie spełniaja Zasady różnicy w wymiarze bezpieczeństwa, ponieważ nie zapewniaja wiele bezpieczeństwa najmniej zabezpieczonym grupom społecznym, szczególnie na współczesnych, „elastycznych” rynkach pracy. Wprawdzie osiagają dość dobry wynik według Zasady antypaternalistycznej 
i Zasady praw przed dobroczynnością, nie robią jednak niczego w kierunku zwiększania wolności; sprawiaja jedynie, że w niektórych przypadkach praca staje się finansowo korzystniejsza. W najlepszym wypadku pensja minimalna jest neutralna wobec Zasady ograniczenia ekologicznego, chociaż przedkłada pracę zużywająca zasoby ponad pracę zachowująca zasoby lub ,reprodukcyjną". Czasy płacy minimalnej jako użytecznego, istotnego elementu polityki społecznej i rynku pracy z pewnością przeminęły.

\section{Ubezpieczenie społeczne}

Przez większość dwudziestego wieku systemy opieki społecznej były oparte na zasadach ubezpieczenia społecznego bazujących na modelach wprowadzonych przez Beveridge'a lub Bismarcka. Istotą tego systemu była solidarność; osoby ubezpieczone na ryzyko o niskim prawdopodobieństwie finansowali osoby ubezpieczone na ryzyko o prawdopodobieństwie wysokim. Ubezpieczano na wypadki nazywane „zdarzeniami losowymi”, jak na przykład bezrobocie, choroba, wypadek, niepełnosprawność lub ciąża. W każdym z przypadków aktuarialne wyliczenia dodatków i świadczeń bazowały na statystycznych prawdopodobieństwach wystapienia tych zdarzeń.

W rzeczywistości systemy ubezpieczeń społecznych nigdy nie były tak solidarnościowe, jak chcieliby ich obrońcy, ani tak uniwersalne, jak wyglądały na pierwszy rzut oka. W szczególnie niekorzystnym położeniu stawiały zwłaszcza kobiety. Działały jednak w miarę dobrze, z szerokim demokratycznym poparciem, dopóki baza składkowa była pewna i szeroka, dopóki wystarczająca liczba osób płaciła składki lub była za nie odprowadzana składka i w końcu dopóki obejmowane nimi ryzyka były tymi, które najbardziej martwiły lub dotykały ludzi.

W dwudziestym pierwszym wieku te warunki już nie obowiązuja. Coraz więcej ludzi wędruje od jednej niestabilnej pracy do drugiej, więc baza składkowa zaczyna się rozpadać, zmuszając rządy do sięgania do ogólnych przychodów w celu zbilansowania budżetu ubezpieczeń społecznych. Z tego samego względu ludzie w coraz mniejszym stopniu są zdolni do wykazania historii składek wymaganej do otrzymania świadczeń z tytułu ubezpieczenia, co uzależnia ich w ciężkich chwilach od polegania na pomocy opartej na kryterium dochodowym. Dodatkowo coraz więcej ludzi jest narażonych na ryzyka, które nie są w wystarczającym stopniu (lub wcale) pokrywane przez ubezpieczenie.

Jednocześnie lepiej zarabiający, mniej narażeni na zdarzenia losowe, sa coraz mniej chętni do składania się na rosnąca liczbę ludzi narażonych na nie w stopniu wysokim. Podważyło to legitymizacje polityczną i poparcie dla świadczeń z tytułu ubezpieczenia społecznego, napędzając żądania cięć w składkach i samych świadczeniach. 
Przede wszystkim nastapiła zmiana w naturze braku bezpieczeństwa ekonomicznego. Członkowie prekariatu maja szczególnie niestabilne przychody, a odczuwany przez nich brak bezpieczeństwa wynika z niepewności, której nie może zaradzić ubezpieczenie społeczne. Ubezpieczenie społeczne działało odpowiednio w warunkach stabilnego, przemysłowego, pełnoetatowego zatrudnienia. Daleko od nich dziś odeszliśmy i prawdopodobnie nie wrócimy do nich w przyszłości.

Ubezpieczenie społeczne w elastycznej gospodarce usługowej nie spełnia Zasady różnicy w wymiarze bezpieczeństwa, chociaż dobrze koresponduje z Zasadą antypaternalistyczną i Zasada praw przed dobroczynnością. Z tego samego powodu, z którego zawodzi płaca minimalna, nie spełnia także Zasady ograniczenia ekologicznego, bo faworyzuje pracę zarobkową wobec pracy społecznie użytecznej. Podsumowując, oferuje ono niewiele osobom najbardziej pozbawionym środków i bezpieczeństwa, nie będąc jednocześnie w stanie promować sprawiedliwości społecznej ani republikańskiej wolności.

\section{Pomoc społeczna oparta na kryterium dochodowym}

Utrata wiary w ubezpieczenie społeczne sprawia, że główną alternatywą wobec dochodu podstawowego staje się pomoc społeczna uzależniona od stanu zamożności, skierowana do osób zidentyfikowanych jako „biedne”. Jest to „główna” alternatywa, ponieważ po jej zaadaptowaniu wprowadzenie innych polityk staje się niemal niezbędne, by całość jakoś funkcjonowała.

Podczas budowania państw dobrobytu w dwudziestym wieku panowało szerokie uznanie dla znanego powiedzenia Richarda Titmussa głoszącego, że świadczenia państwowe przeznaczone tylko dla ubogich to zawsze ubogie świadczenia. Jest tak przede wszystkim ze względu na brak zainteresowania reszty społeczeństwa ich obroną. Kiedy jednak państwa dobrobytu znalazły się w latach 80. i 90. na celowniku, rządy wszelkiej maści zmieniły kurs, kładąc fundamenty pod systemy pomocy społecznej oparte na kryteriach dochodowych, uzasadniane zazwyczaj jako niezbędne dla „obrony” państwa dobrobytu w trudnych czasach.

Idea kryterium dochodowego jest zwodniczo prosta: przeznacz ograniczone środki dla osób, które najbardziej ich potrzebuja. Niższe wydatki umożliwiają niższe podatki. Jednocześnie kryterium dochodowe legitymizuje wydatki państwowe w oczach opinii publicznej, ponieważ politycy moga twierdzić, że pieniądze wędrują do najbardziej potrzebujących. Niestety, kolejne badania wykazują rażące wady tego systemu i sugeruja, że prawdziwym motywem dla wprowadzania kryteriów dochodowych nie jest wcale pomoc biednym. Oto dziesięć spośród tych wad. 
Po pierwsze, pomiar dochodu jest skomplikowany i uwzględnia arbitralne punkty odcięcia. Wliczanie oszczędności i „majątku” zniechęca do oszczędzania, co z kolei zmniejsza odporność w czasach finansowego obciążenia.

Po drugie, sprawdzanie środków wiąże się z wysokimi kosztami zarówno dla administracji, jak i dla wnioskodawców, zmuszonych do podróży do urzędów, stania w kolejkach, wypełniania formularzy, przygotowywania dodatkowych dokumentów itd., na co poświęcają czas i nierzadko pieniądze.

Po trzecie, kryterium dochodowe wymaga zadawania naruszających prywatność pytań, w tym o intymne relacje wnioskodawców, po których moga następować wizyty domowe, na przykład w celu sprawdzenia, czy mieszkania nie zamieszkuje partner przynoszący dodatkowy dochód. Mamy tu więc reżim wścibstwa, naruszenia prywatności i domniemania winy zamiast niewinności, co ubliża zarówno urzędnikom, jak i wnioskodawcom.

Po czwarte, proces i wynik całej procedury jest $\mathrm{z}$ wymienionych względów stygmatyzujący. Często jest to celowe, tak by odstraszyć wnioskodawców i tym samym ograniczyć koszty świadczeń. Słowami jednego z doradców brytyjskiego i amerykańskiego rządu: wnioskodawcy powinni być źle traktowani i zachęcani do obwiniania się o swoją sytuację (Mead 1986). Nie trzeba być chrześcijaninem, by docenić ripostę Malcolma Torry'ego: „świadczenia oparte na kryterium dochodowym, które stygmatyzują swoich odbiorców, nie odzwierciedlaja naszego statusu istot stworzonych na obraz Boga i posiadających godność przewyższaną tylko przez bożą" (Torry 2016, 44).

Prowadzi nas to do piatej wady - niskiego poziomu wykorzystania. Dane z niemal każdego systemu opartego na kryterium dochodowym, w każdym państwie w którym znalazł on zastosowanie, wykazuja, że wiele osób uprawnionych do świadczeń ich nie otrzymuje. Wynika to z wattpliwości wobec zgłaszania wniosku, strachu, wstydu lub niewiedzy; odrzuconego wniosku, prawdopodobnie przez niezrozumienie pytania lub udzielenie „złej” odpowiedzi; i z odmówienia świadczeń z trywialnych powodów (takich jak spóźnienie na spotkanie) przez urzędników niskiego szczebla działających zgodnie z własnym wyobrażeniem o wykonywanej pracy i z myślą o swojej karierze.

W Wielkiej Brytanii wykorzystanie zasiłku dla bezrobotnych, nazwanego zasiłkiem dla szukających pracy (Jobseeker's Allowance, JSA) zawodzi i według szacunków jest on obecnie przyznawany jedynie połowie uprawnionych (Department for Work and Pensions 2016). W roku finansowym 2014-2015 nie zostało przyznanych 2,4 miliarda funtów należnego JSA, co odpowiada 3000 funtów dla każdej z upoważnionych rodzin. Kolejnym świadczeniem o niskim poziomie wykorzystania jest dodatek do emerytur (Pension Credit) mający na celu pomoc ludziom o niskich dochodach, szczególnie kobietom, którzy nie opłacili wystarczającej sumy składek, by kwalifikować się do pełnej emerytury państwowej, lub tym, którzy nie maja innego źródła dochodu oprócz emerytury państwowej. 
W latach 2014-2015, czterech na dziesięciu uprawnionych emerytów nie otrzymało tego dodatku o łącznej wartości 3 miliardów funtów - średnio 2000 funtów na rodzinę.

W Stanach Zjednoczonych tylko jedna czwarta uprawnionych do zasiłku mieszkaniowego opartego na kryterium dochodowym rzeczywiście go odbiera, często po spędzeniu lat na liście oczekujących na kartki, które są emitowane w limitowanej rocznej ilości (Matthews 2014). Program TANF (Temporary Assistance of Needy Families - Tymczasowa pomoc dla rodzin w potrzebie) dociera do mniej niż jednej czwartej rodzin pozostających w ubóstwie mimo wzrostu ogólnej liczby takich rodzin (Center on Budget and Policy Priorities 2016).

Po szóste, kryterium dochodowe podważa solidarność społeczną, oddzielając „nas” od „nich”. My, którzy sami się utrzymujemy, płacimy podatki na utrzymanie ich, naciagaczy. Ta utylitarna perspektywa jest dziś smutną rzeczywistościa, wzmacniana przez zmniejszającą się mobilność społeczną i zdolność bardziej zamożnych do ochrony swoich interesów poprzez prywatne ubezpieczenie i zakumulowany majątek przed jakimkolwiek zagrażającym im ryzykiem.

Siódma, najlepiej znaną wada jest słynna pułapka ubóstwa4. W USA pułapka ubóstwa wynikająca ze stosowania kryterium dochodowego przy przyznawaniu świadczeń oznacza w 35 stanach strate pieniędzy dla ludzi, którzy, uprawnieni do zasiłku, podjęliby pracę za minimalna płacę (stopa „opodatkowania” przekraczająca 100 procent) (Tanner i Hughes 2013). Niektórzy z komentatorów proponowali stopniowe odsuwanie zasiłków po zdobyciu pracy, tak by nie odstraszać od niskopłatnego zatrudnienia. To byłoby jednak nieuczciwe wobec pracujących na stanowiskach oferujących taką samą lub niższą płacę, którzy nie kwalifikowali się wcześniej do świadczeń.

Prowadzi nas to do ósmej wady, nieuniknionego dryfu w kierunku workfare, omówionego bardziej szczegółowo w dalszym podrozdziale. Wobec ludzi o krańcowej stopie opodatkowania przekraczającej 80 procent przy przechodzeniu z zasiłku do niskopłatnej pracy sprawdzanie dochodów stanowi mocno odstraszający czynnik. W takich warunkach państwu pozostaje jedynie zmusić ludzi do podejmowania pracy za niskie wynagrodzenie.

Driewiata wada jest fakt, że stosowanie kryterium dochodowego w pomocy społecznej utrudnia formowanie się stabilnych gospodarstw domowych. Świadczenia są zazwyczaj określane na podstawie gospodarstwa domowego, nie jednostki, a więc w przeliczeniu na osobę są niższe dla par niż jednoosobowych gospodarstw. Po co zakładać gospodarstwo domowe i eksperymentować przy tym, skoro można stracić pieniądze? Dochód podstawowy natomiast, wypłacany indywidualnie i po równo, zachęcałby osoby rozważające życie rodzinne. Byłby

\footnotetext{
4 Pułapkę ubóstwa, razem z pułapką prekarności, autor opisuje w rozdziale 4 książki, a także w swoich monografiach na temat prekariatu (przyp. red.); zob. Standing 2014.
} 
obojętny wobec konfiguracji relacji i gospodarstw, tak jak to powinno być w przypadku kwestii majątkowych.

Driesiata wada odnosi się do stosującego kryterium dochodowe zasiłku dla szukających pracy, który przyznaje się na podstawie całkowitego dochodu rodziny. Jeśli jedno z pary jest bezrobotne, para ta finansowo traci, jeśli druga osoba wykonuje małą ilość płatnej pracy. Opłaca się więc jemu lub jej (a zazwyczaj jest to żona lub partnerka) porzucić tę pracę. Między innymi z tego powodu gospodarstwa domowe w Wielkiej Brytanii w ostatnich latach w coraz większym stopniu dzielą się na bogate (dwoje zatrudnionych) i ubogie w pracę (bez zatrudnionych) (Berthoud 2007).

Pomoc społeczna oparta na kryteriach dochodowych i niezbędnych przy nim testach zachowania narusza wszystkie zasady sprawiedliwości społecznej oraz tę wolności republikańskiej. Powtórzmy - każda polityka przeznaczona tylko dla ubogich jest istotnie zawsze ubogą polityką.

\section{Dotacje i bony żywnościowe}

Jednym z szeroko stosowanych rozwiązań, szczególnie w krajach rozwijających się, jest wprowadzanie dotacji żywnościowych i innych ukierunkowanych na „biednych”. Indyjskie PDS (Public Distribution System - System dystrybucji publicznej) jest największym tego typu systemem, ale istnieje wiele innych. Programy oparte na bonach, takie jak amerykański program bonów żywnościowych SNAP (Supplemental Nutrition Assistance Program - Program pomocy żywnościowej) maja podobne cele. W obu przypadkach sposób rozumowania polega na tym, że skoro ubogim brakuje podstawowych zasobów, państwo powinno dostarczyć im albo środki na ich pozyskanie, albo same zasoby. Kolejnym uzasadnieniem, wykorzystywanym w krajach rozwijających się, jest ochrona ubogich przed wahaniami cen jedzenia (Drèze i Sen $2014)^{5}$.

Istnieje wiele zastrzeżeń wobec tego rodzaju polityki. Po pierwsz̧e i przede wszystkim, takie systemy sa paternalistyczne; zakładaja, że wiedza, czego potrzebuja „biedni”, lepiej od nich samych. Co gorsza, mają na celu dyktowanie, co mogą dostać „biedni”. W Stanach na przykład, bony żywnościowe nie tylko ograniczaja ludzi do kupowania jedzenia, ale często pozwalają im kupować tylko niektóre rodzaje żywności i napojów uznawanych za „zdrowe”.

Systemy bonów i pomoc w naturze opierają się na ukrytym, o ile nie jawnym założeniu, że jeśli ludzie dostana pieniądze, to wydadzą je na mniej istotne produkty, a w szczególności te „złe”, takie jak alkohol, narkotyki lub hazard. Tak naprawdę wiele badań pokazuje, że ludzie

\footnotetext{
5 Temu argumentowi można przeciwstawić koncepcję tworzenia buforowych zapasów żywności, które byłyby uwalniane w momencie wzrostu cen wynikającego z chwilowych niedoborów. Niebezpieczeństwo tego rozwiązania polega na tym, że zniechęca ono lokalnych producentów żywności do zwiększania produkcji.
} 
wcale nie kupują więcej „złych” produktów po otrzymaniu świadczenia w gotówce (Evans i Popova 2014). Zreszta nawet gdyby to założenie było poprawne, to omawiane systemy nie zwiększałyby wolności. Dlaczego biedni, a inni nie, mieliby mieć zakaz wydawania części dodatkowego dochodu na coś, co sprawia im przyjemność? Zawsze zresztą pozostaje możliwość wydania pieniędzy zaoszczędzonych dzięki bonom na „złe” (według nas, dobrych ludzi) produkty albo sprzedania bonów (poniżej wartości) w zamian za gotówkę (Bailey i Pongracz 2015). Odsprzedaż bonów żywnościowych, choć nielegalna, nadal ma miejsce w Stanach Zjednoczonych, ponieważ ludzie potrzebują gotówki na zakup innych niezbędnych im towarów, takich jak pieluchy, których nie można zdobyć za bony.

Po drugie, administracja, dostarczanie i nadzorowanie systemów bonów i dotowanych produktów są kosztowne i wymagaja rozbudowanej biurokracji. Zapewnienie jedzenia o wartości jednej rupii w ramach indyjskiego Systemu dystrybucji publicznej kosztuje rząd 3,65 rupii (Bhalla 2014). Indie mogą być wprawdzie skrajnym przypadkiem, jednak akcje humanitarne ONZ właśnie z tego powodu w coraz większym stopniu polegają na wsparciu finansowym. Jedno z badań porównujących pomoc dostarczaną w formie jedzenia, bonów lub gotówki wykazało, że dostarczanie pomocy w naturze kosztuje niemal czterokrotnie więcej niż ekwiwalent w gotówce (Hidrobo et al. 2014).

Po trzecie, bony są dla beneficjentów warte mniej niż ich ekwiwalent gotówkowy, gotówkę można bowiem wykorzystać wszędzie, natomiast bony są akceptowane tylko w niektórych miejscach albo według uznania sprzedawcy. Zmniejsza to konkurencję o klienta korzystającego z bonów, wobec czego sklepy akceptujące je moga podwyższać ceny. Za bony można więc nabyć mniej niż za gotówkę; istnieje badanie pokazujące, że libańscy sklepikarze akceptujący bony dla syryjskich uchodźców zarabiali w 2014 roku około miliona dolarów miesięcznie dzięki zawyżonym cenom (Bailey i Pongracz 2015). Bony i pomoc w naturze nakładaja przy tym wyższe koszty na swoich odbiorców poprzez wymóg dostania się do wyznaczonych sklepów, czas spędzony na oczekiwaniu itd. (Hidrobo et al. 2014).

Po cźwarte, wiążą się one z kryterium dochodowym i, siłą rzeczy, wszystkimi jego wadami. W Stanach, kraju o stosunkowo wydajnym aparacie administracyjnym, jedna czwarta oficjalnie kwalifikujących się do pomocy nie otrzymuje przeznaczonych dla nich bonów żywnościowych. Co więcej, jedna trzecia tych, którzy je dostają musi także chodzić do banków żywności, inni zaś rezygnują z niektórych posiłków, ponieważ bony pokrywaja zgodnie z oszacowaniami potrzeby żywnościowe tylko na trzy tygodnie w miesiącu (Santens 2016).

Po piate, bony i pomoc w naturze, celowo lub nie, stygmatyzują odbiorców i nadają im status i mentalność petentów. Po šóste, skłaniają do dostarczania towarów i usług niskiej jakości i wywołują wśród administracji pogardę wobec świadczeniobiorców. Bony mieszkalne w Stanach Zjednoczonych kojarzone są z rosnącymi skupiskami ubogich w biednych dzielnicach, w których bony są częściej przyjmowane przez wynajmujących (Mathema 2013). 
Po siódme, bony są narażone na korupcję i/lub pogoń za rentą konkretnych grup interesu. Bony żywnościowe w Stanach Zjednoczonych są żywo promowane przez przedstawicieli Partii Republikańskiej z rolniczych stanów. W Indiach do biednych trafia mniej niż 10 procent jedzenia kupowanego przez rząd w ramach Publicznego systemu dystrybucji; prawie połowa znika w tajemniczych warunkach w drodze z magazynu do miejsca wydawania, a większa część reszty gnije w rządowych składach (Mathema 2013). Przejście na system dochodu podstawowego, bazującego na bezpośredniemu przyznaniu gotówki świadczeniobiorcom, za jednym zamachem zlikwidowałoby warstwy pośredników i potencjalny lobbing.

Dotacje żywnościowe i im podobne wydają się spełniać Zasadę różnicy w wymiarze bezpieczeństwa dzięki temu, że docieraja do najmniej zabezpieczonych grup społecznych, jednak niektóre osoby $z$ tych grup są wyłączone $z$ takich systemów pomocy. Bony z pewnością łamią też Zasadę antypaternalistyczną i Zasadę praw przed dobroczynnością. Oprócz tego są kosztowne w zarządzaniu, nieefektywne i powiązane z korupcją i pogonią za rentą. W Ekwadorze przeprowadzono doświadczenie polegające na przyznawaniu wielu niezależnym grupom pomocy gotówkowej, bonów żywnościowych i bezpośrednio jedzenia. Okazało się, że jedynie mniej niż 10 procent otrzymujących gotówkę wolałoby inną formę pomocy, natomiast jedna czwarta lub jedna trzecia pozostałych pragnęła zmiany (Hidrobo et al. 2014). Badani, którzy otrzymali gotówkę, cenili sobie możliwość wydania części pieniędzy na inne niezbędne produkty oraz oszczędzania. To i wiele innych badań pokazuje, że ludzie wola gotówkę niż to, czego zdaniem biurokratów najbardziej im brakuje.

\section{Gwarancja zatrudnienia}

Niektórzy twierdzą, że „gwarancja zatrudnienia” byłaby korzystniejsza niż dochód podstawowy, ponieważ praca posiada jakąś dająca szczęście, integralną wartość, wykraczająca poza uzyskiwany dochód (poczucie przynależności i wkładu w społeczność, uporządkowanie czasu, interakcja z innymi pracownikami i tak dalej). Zwolennicy gwarancji zatrudnienia to między innymi Lord (Richard) Layard w Wielkiej Brytanii, były „car szczęścia” Tony’ego Blaira (Gregg i Layard 2009), i Harvey oraz Quigley w Stanach Zjednoczonych (wcześniej zaś Minsky) (Harvey 2003; Harvey 2013; Quigley 2003; Minsky 2013).

Wattpliwości wobec tej polityki częściowo odnoszą się do następnej z możliwych polityk, czyli workfare. Gwarancja zatrudnienia byłaby zwodnicza. Jaki rodzaj zatrudnienia bylibyśmy w stanie zagwarantować? Za jaka stawkę? Jaka byłaby konsekwencja odrzucenia oferty konkretnego zagwarantowanego miejsca pracy? Kompletną mrzonką jest zagwarantowanie każdemu pracy, która go interesuje, wykorzystuje jego zdolności i jest dobrze opłacana, więc w praktyce mielibyśmy do czynienia z zatrudnieniem na niskim szczeblu, źle 
opłacanym, krótkoterminowym, nieprzydatnym albo przynajmniej mało produktywnym. Sprzątanie ulic, ustawianie towaru na półkach i inne proste prace raczej nie stanowia drogi do szczęścia. Zwolennicy gwarancji zatrudnienia z pewnością nie chcieliby takiego zatrudnienia dla siebie ani swoich dzieci.

Jednym z powodów poparcia dla gwarancji zatrudnienia są badania sugerujące, że bezrobotni są mniej szczęśliwi niż zatrudnieni. Nic dziwnego. Przymusowe bezrobocie przy nędznym, trudnym do zdobycia i zachowania, stygmatyzującym i niepewnym zasiłku nie stanowi szczęśliwej sytuacji. Co innego dobrowolne pozostawanie bez pracy, nienapiętnowane i z bezpieczeństwem dochodu. Jak pisała Kate McFarland „,nie chodzi o to, że nasza kultura ceni zatrudnienie, które samo w sobie nas uszczęśliwia; chodzi raczej o to, że często sprawia ono, że jesteśmy szczęśliwsi, bo utknęliśmy w kulturze ceniącej zatrudnienie" (McFarland 2016). Mimo to sondaże Gallupa konsekwentnie pokazują, że mniej niż jedna trzecia amerykańskich pracowników czuje się zaangażowana (pełna entuzjazmu i poświęcona zajęciu) w swoją pracę, ze szczególnym uwzględnieniem millenialsów i wykonujących mało cenione, rutynowe zawody. Na całym świecie poniżej jednej piątej zatrudnionych czuje zaangażowanie.

Propozycje szerzenia zatrudnienia, na przykład poprzez skrócenie czasu pracy, często przechodzą w gwarancję zatrudnienia. Emran Mian, dyrektor Social Market Foundation, jest za redystrybucja pracy „nawet, jeśli miałaby zmniejszyć wydajność ekonomiczna, zamiast rozdawać pieniądze" (Mian 2016). New Economics Foundation podaje, że krótszy tydzień pracy zmniejszyłby bezrobocie (Coote i Franklin 2013). Trudno jednak uwierzyć, by można to było osiagnąć na drodze regulacji prawnych, o czym przekonali się Francuzi z ich trzydziestopięciogodzinnym tygodniem. Ustawowa redukcja czasu pracy bez wsparcia dochodem podstawowym doprowadziłaby do zubożenia wielu ludzi pracujących za niskie płace i nie przysłużyłaby się stworzeniu nowych miejsc pracy.

Większość rzeczników gwarancji zatrudnienia ignoruje także fakt, że gospodarki rynkowe potrzebuja pewnego poziomu bezrobocia do poprawnego funkcjonowania. Klasyczny artykuł autorstwa A.W. Phillipsa z 1958 roku wskazuje na odwrotną relację między poziomem bezrobocia a stopa inflacji. Mimo że dokładny powód tego związku do tej pory jest przedmiotem dyskusji, wielu ekonomistów uznaje „naturalny” poziom bezrobocia zapewniający stabilną inflację (zwykle określany jako NAIRU lub bezrobocie stabilizujące poziom inflacji). W gospodarce rynkowej żaden rząd nie jest więc w stanie zagwarantować zatrudnienia każdemu chętnemu.

Gwarancja zatrudnienia, o ile da się ją zoperacjonalizować, mogłaby spełniać Zasadę różnicy w wymiarze bezpieczeństwa, gdyby istniała możliwość zapewnienia odpowiednich miejsc pracy wszystkim osobom z niepełnosprawnością lub ograniczeniami. Wydaje się to jednak mało prawdopodobne. Miejsca pracy zazwyczaj wędrują do ludzi młodych, z zamiarem zapobieżenia ich „marginalizacji”. Omawiana polityka z pewnością narusza wolność 
republikańską oraz warunki sprawiedliwości społecznej, ponieważ narzucając obowiązki na pewne grupy, nie narzuca ich na najbardziej wolnych; oprócz tego stwarza zasadę dobroczynności przed prawami. Czy rzeczywiście każda osoba mogłaby mieć zagwarantowane pożądane zatrudnienie, albo chociaż takie, które odpowiada jej kompetencjom? Trudno to sobie wyobrazić.

\section{Workfare}

Workfare stanowi naturalną konsekwencję reform państwa dobrobytu mających miejsce od lat 80. Zgodnie z tym, co dawno temu przewidzial autor (Standing 1990) ${ }^{6}$, po tym jak rzady zadecydowały o wznowieniu kryterium dochodowego jako jednego z głównych elementów systemu zabezpieczenia społecznego, wprowadzenie workfare było nieuchronne.

Jeśli pomoc społeczna opiera się na wskazywaniu „biednych”, wkrótce powstaje rozróżnienie między tymi, którzy są biedni bez swojej winy, oraz tymi, którzy „wybrali” biedę albo stali się biedni przez swoje błędy i osobiste niepowodzenia. Ta ograna dychotomia znana jest od zarania polityki społecznej i „dobroczynności”. Kiedy jednak decydenci idą tą droga, zmuszeni są do podjęcia następnego arbitralnego rozróżnienia. Tylko ci, którzy zaakceptują pracę proponowana przez państwo w zamian za świadczenie ,zasługują" na to świadczenie. Inaczej należy ich „objąć sankcjami”.

Workfare w jego nowoczesnym kształcie narodził się w latach 80. w amerykańskim stanie Wisconsin, gdzie przedstawiciele Partii Republikańskiej wprowadzili wymóg przyjęcia z konieczności niskopłatnej pracy dla wszystkich ubiegających się o zasiłek. Jak się można spodziewać, zmniejszyło to liczbę wniosków, co miało rzekomo dowodzić, że wcześniej wiele osób oszukiwało, zgłaszając się po świadczenia, lub też ich wcale nie potrzebowało.

Republikanie niebawem poparli to rozwiązanie w Kongresie, przygotowując projekt epokowej reformy prezydenta Billa Clintona z 1996 roku, która wypełniła jego obietnicę wyborczą o „końcu opieki społecznej, jaką znamy”. Personal Responsibility and Work Opportunity Reconciliation Act ograniczył czas otrzymywania przez ludzi zasiłków, wprowadził ściślejsze kryteria kwalifikacji i narzucił wymagania dotyczące zatrudnienia. „Zasiłek-za-pracę” stał się później mantra polityków i partii trzeciej drogi na całym świecie, zaś regulacje w duchu workfare rozprzestrzeniły się na wszystkie kraje uprzemysłowione.

Brakuje wprawdzie miejsca na szczegółową analizę tego doświadczenia, jednak istnieje wiele dowodów na to, że amerykański workfare obniżył wydatki na opiekę społeczną kosztem wpadnięcia wielu rodzin w jeszcze trudniejszą sytuację materialną (The Economist 2016, 1112). To samo można powiedzieć o programach workfare w innych krajach, które spychają ludzi

\footnotetext{
${ }^{6}$ Argument ten został potem rozwinięty w Karcie Prekariatu (Standing 2015).
} 
do wykonywania niskopłatnych prac albo odcinają zasiłek tym, którzy odmawiaja lub nie sa w stanie ich podejmować. Niezależnie jednak od tych wyników, workfare jest szkodliwa polityka.

Workfare zawiera w sobie przymus i narzucenie „obowiązu pracy” na świadczeniobiorców, które jednocześnie nie obejmuja innych. Jest także paternalistyczny w swoim założeniu, że państwo najlepiej wie, co jest najlepsze dla jednostki i dla społeczeństwa. Stanowisku głoszącemu rozwijanie umiejętności i „nawyku pracy” przez workfare przeczy rodzaj zatrudnienia oferowanego bezrobotnym, podobnie zresztą twierdzenie o integracji społecznej przez workfare jest nieprawdziwe, ponieważ ludzie bez zatrudnienia są w tym układzie społecznie zmarginalizowani lub ,wykluczeni”.

Spychanie ludzi w nierozwojowe, krótkoterminowe zatrudnienie utrudnia im ich własne poszukiwania pracy, naukę lub szkolenie, potencjalnie żmniejszajac ich możliwości wymknięcia się z ubóstwa i niepewności ekonomicznej. Istnieją nawet dowody na obniżenie dochodów na przestrzeni życia przez udział w workfare, co miałoby wynikać z kierowania ludzi do prostych, tymczasowych prac niepasujących do ich kwalifikacji i doświadczenia (Collins 2008).

Workfare ma także dysfunkcyjny i deformujący wpływ na rynek pracy. Wywiera nacisk na obniżanie płac przez dostarczanie taniej siły roboczej konkurującej z zatrudnionymi na podobnych stanowiskach na otwartym rynku pracy. Ludzie ci, już należący do najbardziej narażonych i pozbawionych bezpieczeństwa, mogą nawet stracić pracę dlatego, że da się ich zastapić przez uczestników workfare.

Główne polityczne powody istnienia workfare nie maja nic wspólnego z „uszczęśliwianiem” ludzi. W rzeczywistości wynikają jedynie z chęci obniżenia zobowiązań państwa wobec gorzej sytuowanych i faktu, że rządy nie dysponują wieloma środkami poza przymusem w warunkach programów pomocy społecznej opartych na kryterium dochodowym zniechęcających finansowo do podejmowania niskopłatnej pracy. Ten ciąg argumentacyjny ma swoje źródło w wadliwym projekcie. Workfare narusza Zasadę różnicy w wymiarze bezpieczeństwa, krzywdząc najmniej zabezpieczonych. Celowo narusza także Zasadę antypaternalistyczną. Jest w końcu polityką sprzeczną $\mathrm{z}$ jakąkolwiek wizją wolności i sprawiedliwości społecznej.

\section{Ulgi podatkowe}

Ulgi podatkowe stały się domyślną opcja rządów socjaldemokratycznych w państwach rozwiniętych od czasu zaistnienia nacisku na płace związanego z globalizacją i „elastycznymi” rynkami pracy. Ulgi podatkowe bilansują niskie płace do poziomu zarabianego przychodu. Z konieczności systemy tego typu są złożone i opierają się na raczej arbitralnych warunkach uprawnienia. 
Ulgi podatkowe zaczęły się w Stanach skromnie, od Earned Income Tax Credit (EITC) w latach 70. Następnie znacznie rozwinięto je podczas prezydentury Billa Clintona w latach 90., co sprawiło, że stały się najdroższym systemem pomocy społecznej na świecie, kosztując niemal 80 miliardów dolarów rocznie. Jedna czwarta wszystkich Amerykanów jest uprawniona do ulg podatkowych, a ponad 26 milionów otrzymało je w roku podatkowym 2015, co daje średnio 3200 dolarów na rodzinę z dziećmi. Dorośli nie posiadający dzieci są w większości wykluczeni z systemu.

W Wielkiej Brytanii ulgi podatkowe miały także skromny początek w 1999 roku. Ulgi podatkowe, będące dodatkami dla osób o niskich zarobkach (Working Tax Credits) oraz ulgi podatkowe na dzieci (Child Tax Credits) dla rodziców o niskich dochodach zostały wprowadzone w 2003 roku i stały się kluczowe dla reform społecznych i rynku pracy przeprowadzanych przez Nową Partię Pracy. Do lat 2013-2014 koszt programu urósł do 30 miliardów funtów rocznie, co stanowi 14 procent całych wydatków na opiekę społeczną, a liczba zależnych od ulg podatkowych wzrosła do 3,3 miliona z nieco ponad 2 milionów dziesięć lat wcześniej. Włączając w to dopłaty do czynszu i podatku miejskiego dla zatrudnionych, wydatki rządu na kompensację niskich płac wzrosły do 76 miliardów funtów rocznie, co stanowi jedną trzecią wszystkich wydatków na pomoc społeczną i z pewnością największy transfer społeczny, nie licząc emerytur (Ferguson 2015).

Brytyjskie ulgi podatkowe są włączane w nowy system Powszechnego kredytu, który łączy niektóre świadczenia, jednak obciążony jest tymi samymi wadami, co ulgi podatkowe dla pracujących i inne świadczenia objęte kryterium dochodowym. Główną z nich jest nieszczęsna pułapka ubóstwa o krańcowej stopie „podatkowej” dochodów sięgającej 80 procent lub więcej. W Stanach podobne, a nawet wyższe stopy „podatkowe” zniechęcają do zwiększenia przychodów, kiedy ulgi przestaja obowiązywać. Z pewnością zarówno w Stanach, jak i w Wielkiej Brytanii system ten sprawił, że mniej zarabiający członkowie gospodarstw domowych uprawnionych do ulg, zazwyczaj kobiety w związkach małżeńskich, zaczęli zmniejszać wymiar godzin płatnej pracy lub opuszczać rynek pracy (Nichols i Rothstein 2016; Brewer i Browne 2006).

Ulgi podatkowe rodzą też błędy i drobne oszustwa. Zgodnie $z$ danymi Amerykańskiego urzędu podatkowego około jedna czwarta wszystkich ulg podatkowych jest zgłaszana nieprawidłowo, generując koszty w wysokości 14 miliardów dolarów rocznie (Tanner 2015, 17). Przeciwnicy pomocy społecznej wskazują na oszustwa, niektóre lub nawet większość z nich może jednak wynikać ze złożoności systemów, która prowadzi do błędów i nieporozumień. W Wielkiej Brytanii odbiorcy ulg podatkowych musza podawać urzędowi skarbowemu oszacowanie dochodów - może to być trudne, a nawet niemożliwe, jeśli dochody i przepracowane godziny często ulegają zmianom. Jeśli dochody ukazują się przewyższać 
oszacowanie, korzystający z ulg, zgodnie z definicją mało zarabiający, są zmuszeni do zwrotu nadpłaty, co prowadzi ich do dalszego zubożenia i wzrostu zadłużenia (Rawlinson 2014).

Ulgi podatkowe dotuja kapitał, niezależnie od ich wpływu na ubóstwo i dochody pracowników najemnych. Jedno z oszacowań wskazuje, że w Stanach Zjednoczonych każdy dolar przeznaczony na EITC wiąże się z zyskiem 73 centów dla pracownika, zaś 27 centów dla pracodawcy - dzięki niższym płacom (Rothstein 2009). Podobnie w wypadku Wielkiej Brytanii naukowcy doszli do wniosku, że trzy czwarte wartości ulg podatkowych wędruje do pracowników, reszta do pracodawców (The Economist 2015).

Oczywistą wadą ulg podatkowych jest fakt, że, z kilkoma wyjątkami, pomagają jedynie zatrudnionym. Ci, którzy nie mogą zdobyć pracy, lub z jakiegoś powodu nie pracuja zostaja wyłączeni. Ulgi podatkowe blokują też postęp technologiczny. Redukcja kosztów pracy obniża wywieraną na przedsiębiorcach presję do wprowadzania zwiększających produktywność innowacji. W końcu, ulgi podatkowe łamia zasady sprawiedliwości społecznej oraz wolności i maja przewrotne skutki ekonomiczne i na rynku pracy.

\section{Powszechny kredyt}

W trakcie pisania tej książki na początku 2017 roku brytyjski rząd nadal przechodził przez niezwykle długi i kosztowny proces wprowadzania tak zwanego „Powszechnego kredytu”. Po ogłoszeniu w 2010 roku, funkcjonował on od roku 2013 w bardzo ograniczonej skali i, po serii opóźnień i utrudnień, ma zostać w całości wprowadzony do 2022 roku. Plan ten jest unikatowy w przypadku Wielkiej Brytanii, ucieleśnia jednak wiele elementów występujących globalnie w reformach polityki społecznej.

Powszechny kredyt nie jest ani „powszechny”, ani nie jest „kredytem”. Ma na celu integrację sześciu oddzielnych świadczeń opartych na kryterium dochodowym oraz ulg podatkowych, nie można go więc nazwać „powszechnym”, bo kierowany jest tylko do mało zarabiających. Uwzględnia też ścisłe obwarowania dotyczące zachowania, co obraca w ponury żart słowo „powszechny”.

Jednostki lub gospodarstwa domowe otrzymają miesięcznie wypłacany transfer dochodów wyrównujący kwotę, którą zarobili w poprzednim miesiącu, licząc od konkretnego dnia. Nie uwzględnia to faktu, że dochody wielu nisko uposażonych gospodarstw domowych wahają się z miesiąca na miesiąc i z tygodnia na tydzień, na przykład wraz ze zmianą liczby przepracowanych godzin ${ }^{7}$. Przeprowadzone w Stanach badanie wykazało, że trzy czwarte osób z dolnych 20 procent zarabiających doświadczyło miesięcznych zmian dochodowych wynoszących 30 procent lub więcej (cyt. za Painter 2016). Wypłata zaległości oznacza, że nie

${ }^{7}$ Doskonałą krytykę Powszechnego kredytu przedstawiły Jane Millar i Fran Bennett (2016). 
jest to „kredyt” ani tym bardziej z góry znana kwota. Do tego bazowanie na poprzednim miesiącu nie odzwierciedla bieżących warunków.

Z Powszechnym kredytem wiąże się niebezpieczna pułapka ubóstwa o progu 63 procent. Po doliczeniu podatku i ubezpieczenia społecznego, a przy tym utracie uzależnionego od dochodu i niewliczonego w Powszechny kredyt zasiłku na podatek lokalny, świadczeniobiorcy moga mieć do czynienia z krańcową stopą opodatkowania przekraczająca 80 procent licząc od całkowitego dochodu. Pułapkę prekarności pogłębia z kolei przepis o czterdziestodwudniowym okresie oczekiwania na pierwsza płatność (do 60 dni, wliczając w to opóźnienia administracyjne), co spycha wielu wnioskodawców w zadłużenie, zaległości czynszowe i uzależnienie od banków żywności.

Powszechny kredyt jest w większym stopniu obwarowany warunkami i karzący niż świadczenia, które ma zastąić, ponieważ narzuca wymóg „zaangażowania wnioskodawcy” nie tylko na bezrobotnych szukających i podejmujących pracę, ale także zatrudnionych na część etatu, zmuszonych do poszukiwania dodatkowych godzin. Świadczeniobiorcy uznani za niewystarczająco zdeterminowanych do pracy na pełny etat moga utracić zasiłek nawet na trzy lata. System ten rozciąga warunkowy charakter świadczeń na większą grupę ludzi niż wcześniej, włączając w to partnerów osób zatrudnionych.

Wnioskodawcy będa monitorowani w pracy i poza nią przez „trenerów pracy” i „doradców wsparcia rozwoju”, by upewnić się, że spełniają warunki. Koszty armii trenerów pracy z pewnością będą olbrzymie, a nawet jeśli nie, to rozwiązanie to skazane jest na porażkę. Decydenci mogą łudzić się, że ten orwellowski z ducha pomysł służy pomocy, jednak w istocie jest paternalistyczny, inwazyjny, stygmatyzujący i prowadzi do codziennych upokorzeń zmuszających niektórych z wnioskodawców do wycofania się z systemu z powodu wstydu. Pojawiają się jednak niestety sygnały, że taki właśnie obrót spraw jest pożądany. „Zaangażowanie wnioskodawców” jest wprawdzie porównywane przez twórców do umowy zatrudnienia, nie ma z nia jednak nic wspólnego, skoro jest wnioskodawcom narzucane, a powodujące zubożenie sankcje moga być wymierzane przez biurokratów bez rzetelnego procesu.

Co więcej, Powszechny kredyt przez uzależnienie od kryterium dochodowego w stosunku do gospodarstwa domowego zachęca do zakładania i utrzymywania jednoosobowych gospodarstw. Druga osoba w związku zarabia mniej niż pierwsza, dlatego, przewrotnie, Powszechny kredyt zachęca też pary do zrywania. Od 2016 roku świadczenie nie jest wypłacane dla trzeciego i kolejnych dzieci, tylko dla pierwszych dwóch. Powszechny kredyt jest więc moralistyczny i karze duże rodziny, mogące mieć większe potrzeby.

Najgorszą cechą Powszechnego kredytu jest opieranie go na groźbach i sankcjach zamiast zachęty do pracy. Wywiera przez to nacisk na obniżanie płac i pogłębia nierówności na rynku pracy. Trudno brać na poważnie oświadczenia rządu, jakoby „Powszechny kredyt 
wypełniał obietnicę rządu dotyczącą przemiany warunków społecznych z niskich płac i wysoką pomoc społeczną na wysokie płace i niskie zasiłki” (Department for Work and Pensions 2015). Nie ma możliwości, by Powszechny kredyt spowodował wzrost płac. Poza tym w przeciwieństwie do dochodu podstawowego wyraźnie faworyzuje pracę zarobkową a dyskryminuje inne, potencjalnie bardziej wartościowe formy pracy.

Wymienione wcześniej rażące wady Powszechnego kredytu sprawiają, że zachowanie polityków i badaczy społecznych bezczynnie przyglądających się jego wprowadzaniu trzeba uznać nie tylko za zaskakujące, ale i hańbiące. Każdy troszczący się o wolność i sprawiedliwość powinien krytykować reżim grożący zubożeniem ludzi bez rzetelnego procesu, wprowadzający system szpicli ścigających pozbawionych bezpieczeństwa ludzi i promujący wykluczenie, zniechęcający do podjęcia pracy i stygmatyzujący poprzez promowanie kryterium dochodowego. Powszechny kredyt prawdopodobnie zepchnie więcej ludzi w niskopłatne prace, a w ogólnym rozliczeniu obniży też płace prekariatu.

Parlamentarzyści Frank Field i Andrew Forsey podsumowują: „historycy polityczni moga być zainteresowani tym, w jaki sposób program w takim stopniu zagrożony ryzykiem i potencjalnie kosztowny stał się flagowym programem reformy pomocy społecznej rządzącej koalicji przy znikomej debacie publicznej i rządowej” (Field i Forsey 2016, 73).

\section{Negatywny podatek dochodowy}

Propozycja negatywnego podatku dochodowego (NPD), kojarzona przede wszystkim z Miltonem Friedmanem, często postrzegana jest jako forma dochodu podstawowego, sam Friedman $z$ reszta przedstawiał ją w taki sposób, między innymi w wiadomości przesłanej do BIEN (Basic Income Earth Network, Światowa sieć dochodu podstawowego). Należy jednak podkreślić dwie podstawowe różnice. Negatywny podatek dochodowy związany byłby z dochodem lub zarobkami rodriny i (podobnie jak ulgi podatkowe w Stanach Zjednoczonych) wypłacany z moca wsteczną po zakończeniu roku podatkowego. Tak naprawdę byłby to selektywny system oparty na kryterium dochodowym ze wszystkimi jego wadami.

Drugi z aspektów oznacza, że wypłacana kwota nie byłaby znana z wyprzedzeniem i prawie na pewno nie byłaby dostępna w momencie najpilniejszej potrzeby. Przypominałoby to raczej nadzwyczajne zyski (albo roczne odsetki od kapitału) niż bezpieczeństwo wynikające ze stałego źródła podstawowego dochodu.

Co więcej, amerykańskie eksperymenty z NPD w latach 70. XX wieku pokazały, że ludzie dostawali bodziec do zaniżania zgłaszanej pracy i zarobków tak, by otrzymać dodatek z tytułu NPD. Dochód podstawowy nie stwarzałby tego rodzaju pokusy nadużyć. Podsumowując powyższe, negatywny podatek dochodowy nie wypada tak dobrze, jak dochód podstawowy w stosunku do zasad sprawiedliwości społecznej. 


\section{Prywatna dobroczynność}

W końcu, niektórzy utrzymuja, że państwo powinno wycofać się ze wszelkich form pomocy społecznej i pozostawić opiekę nad ludźmi w potrzebie jednostkom i „organizacjom charytatywnym”. Prawicowi libertarianie chcieliby w idealnych warunkach bazować w całości na dobroczynności, nie chca jednak tego przyznać, ponieważ masowa hojność na wymagana skalę byłaby zbyt wielkim oczekiwaniem. Istnieja jednak bardziej fundamentalne racje przemawiające przeciwko poleganiu w większym stopniu na dobroczynności i filantropii.

Dobroczynność opiera się na poczuciu „litości”, a, jak zauważył filozof David Hume, od litości blisko do pogardy. Prywatna dobroczynność jako główny filar polityki społecznej mogłaby zadowolić libertarian, ale poważnie narusza centralną ideę republikańskiej wolności od dominacji. Poleganie na dobrej woli innych jest niespójne z pełną wolnością. Wręcz przeciwnie, narusza wolność darczyńcy, tak samo jak obdarowanego.

Rozprzestrzenianie się dobroczynności w znacznym stopniu odzwierciedla wielorakie wady pomocy społecznej opartej na kryterium dochodowym, nieuczciwości wyznaczania warunków, celowych sankcji obarczających najbardziej narażonych ludzi i szerzeniu niepewności ekonomicznej. W Wielkiej Brytanii, dla przykładu, ponad 40 procent skierowań do banków żywności kierowanych przez dużą organizację charytatywną Trussell Trust wynika z opóźnień w wypłacie świadczeń oraz sankcji (Harrison-Evans 2016).

Fakt, że wielu ludzi w współczesnym społeczeństwie udaje się do banków żywności i schronisk wskazuje na klęskę polityki społecznej. Prywatna filantropia powinna na powrót zostać zmarginalizowana, stanowi bowiem niedemokratyczny sposób kształtowania społeczeństwa i wybiórczego dobrobytu jednostek, grup i społeczności.

\section{Klęska alternatyw}

Większość alternatyw wobec dochodu podstawowego wypada źle w stosunku do zasad sprawiedliwości społecznej, co pokazuje tabela poniżej. Niektórzy mogą spierać się z niektórymi aspektami, szczególnie biorąc pod uwagę zakładaną neutralność alternatyw do dochodu podstawowego wobec konsekwencji ekologicznych. Systemy ukierunkowane na miejsca pracy, na przykład, maja tendencję do przedkładania tworzenia krótkoterminowego zatrudnienia kosztem ochrony środowiska. Główny wniosek jest jednak taki, że wszystkie alternatywy wypadaja gorzej od dochodu podstawowego. 


\begin{tabular}{|c|c|c|c|c|c|}
\hline & $\begin{array}{c}\text { Zasada } \\
\text { różnicy w } \\
\text { wymiarze } \\
\text { bezpie- } \\
\text { czeństwa }\end{array}$ & $\begin{array}{c}\text { Zasada } \\
\text { antypaterna- } \\
\text { listyczna }\end{array}$ & $\begin{array}{l}\text { Zasada praw } \\
\text { przed } \\
\text { dobroczyn- } \\
\text { nością }\end{array}$ & $\begin{array}{c}\text { Zasada } \\
\text { ograniczenia } \\
\text { ekolo- } \\
\text { gicznego }\end{array}$ & $\begin{array}{c}\text { Zasada } \\
\text { godnej pracy }\end{array}$ \\
\hline Płaca minimalna & Nie & Tak & Tak & nd & nd \\
\hline $\begin{array}{l}\text { Ubezpieczenie } \\
\text { społeczne }\end{array}$ & Nie & Tak & Tak & nd & nd \\
\hline $\begin{array}{l}\text { Pomoc społeczna } \\
\text { oparta na kryterium } \\
\text { dochodowym }\end{array}$ & Nie & Nie & Nie & nd & Nie \\
\hline $\begin{array}{l}\text { Bony } i \\
\text { dofinansowania }\end{array}$ & Nie & Nie & Nie & nd & nd \\
\hline $\begin{array}{l}\text { Gwarancja } \\
\text { zatrudnienia }\end{array}$ & Nie & Nie & Nie & nd & Nie \\
\hline Workfare & Nie & Nie & Nie & nd & Nie \\
\hline Ulgi podatkowe & Nie & Tak & Tak & nd & Nie \\
\hline $\begin{array}{l}\text { Negatywny podatek } \\
\text { dochodowy }\end{array}$ & Nie & Tak & Tak & nd & Nie \\
\hline $\begin{array}{l}\text { Prywatna } \\
\text { dobroczynność }\end{array}$ & Nie & Nie & Nie & nd & Nie \\
\hline Dochód podstawowy & Tak & Tak & Tak & Tak & Tak \\
\hline
\end{tabular}

Tabela 1. Zgodność różnych systemów opieki społecznej z zasadami sprawiedliwości społecznej. 
Obrońcy istniejących systemów pomocy społecznej powinni wyjaśnić dlaczego, mimo rosnących wydatków, wskaźniki ubóstwa uparcie pozostają na wysokim poziomie, a mobilność społeczna wydaje się zmniejszać. W Stanach Zjednoczonych, po ostrym spadku w okresie od lat 60. do mniej więcej 1979 roku, wskaźnik ubóstwa prawie się nie zmienia. Znaczne nakłady na świadczenia oparte o kryterium dochodowe, ulgi podatkowe, workfare, bony żywnościowe i inne ze 126 wyliczanych przez ekspertów systemów przeciwdziałających ubóstwu nie przyniosły wyraźnej poprawy (Tanner 2015, 14). Jest to z pewnością sygnałem, że potrzeba nam nowej drogi. 


\section{Wykaz literatury}

Bailey, Sarah i Sophie Pongracz. 2015. Humanitarian Cash Transfers: Cost, V alue for Money and Economic Impact. London: Overseas Development Institute.

Berthoud, Richard. 2007. Work-Rich and Work-Poor: Three Decades of Change. York: Joseph Rowntree Foundation.

Bhalla, Surjit, S. 2014. „Dismantling the welfare state”. Livemint, 11 czerwca.

Brewer, Mike i James Browne. 2006. The Effect of the Working Families' Tax Credit on Labour Market Participation. Briefing Note No. 69. London: Institute for Fiscal Studies.

Center on Budget and Policy Priorities. 2016. „Chart book: TANF at 20”. cbbb.org, 5 sierpnia.

Collins, Jane Lou. 2008. „The specter of slavery: Workfare and the economic citizenship of poor women". W New Landscapes of Inequality: Neoliberalism and the Erosion of Democracy in America, red. Micaela Di Leonardo, Jane Lou Collins i Brett Williams. Santa Fe: SAR Press: 131-152.

Coote, Anna i Jane Franklin (red.). 2013. Time on Our Side: Why We All Need a Shorter Working Week. London: New Economics Foundation.

Department for Work and Pensions. 2015. Universal Credit at Work. Londyn: Department for Work and Pensions.

https://www.gov.uk/government/uploads/system/uploads/attachment_data/file/483 029/ucredit-at-work-december-2015.pdf.

Department for Work and Pensions. 2016. „Income-related benefits: Estimates of take-up”. DWP, 28 lipca.

Drèze, Jean i Amartya Sen. 2014. An Uncertain Glory: India and Its Contradictions. Princeton: Princeton University Press.

Evans, David K. i Anna Popova. 2014. „Cash Transfers and Temptation Goods: A Review of the Global Evidence”. World Bank Policy Research Working Paper WPS6886.

Washington: World Bank.

Ferguson, James. 2015. „Prepare for tax hikes”. Money Week, 11 marca.

Field, Frank, i Andrew Forsey. 2016. Fixing Broken Britain? An Audit of Working- Age Welfare Reform Since 2010. London: Civitas.

Gregg, Paul i Richard Layard. 2009. A Job Guarantee. Londyn: Centre for Economic Performance Working Paper, London School of Economics. http://cep.lse.ac.uk/textonly/_new/staff/layard/pdf/001JGProposal-16-03-09.pdf.

Harrison-Evans, Peter. 2016. „A universal basic income: What would it mean for charities?”. New Philanthropy Capital, 16 sierpnia. http://www.thinknpc.org/blog/a-universal-basicincome-what-would-it- mean-for-charities/.

Harvey, Philip. 2005. „The right to work and basic income guarantees:Competing or complementary goals?". Rutgers Journal of Law and Urban Policy 2(1): 8-59.

Harvey, Philip. 2013. „More for less: The job guarantee strategy”. Basic Income Studies 7(2): 318.

Hidrobo, Melissa et al. 2014. „Cash, food, or vouchers? Evidence from a randomized experiment in northern Ecuador". Journal of Development Economics 107: 144-56.

Lawrence, Felicity. 2016. „Beyond parody: HMRC cleaners left worse off after introduction of the national living wage". Guardian, 28 lipca.

Mathema, Silva. 2013. „Undue concentration of housing choice voucher holders: A literature review". Poverty and Race Research Action Council (PRRAC). 
http://www.prrac.org/pdf/Undue_Concentration_of_Vouchers_-_lit_review_613.pdf.

Matthews, Dylan. 2014. „76 percent of people who qualify for housing aid don't get it”. Vox, 31 maja. http://www.vox.com/2014/5/31/5764262/76- percent-of-people-whoqualify-for-housing-aid-dont-get-it.

McFarland, Kate. 2016. „Basic income, job guarantees and the non-monetary value of jobs: Response to Davenport and Kirby". Basic Income News, 5 września.

Mead, Lawrence M. 1986. Beyond Entitlement: The Social Obligations of Citizenship. New York: Free Press.

Mian, Emran. 2016. „Basic income is a terrible, inequitable solution to technological disruption". TheLong+Short, 21 lipca. https://thelongandshort.org/growth/againstbasic-income.

Millar, Jane i Fran Bennett. 2016. „Universal credit: Assumptions, contradictions and virtual reality". Social Policy and Society, 10 maja. DOI: 10.1017/S1474746416000154. iscepi

Minsky, Hyman P. 2013. „The macroeconomics of a Negative Income Tax”. W Ending Poverty: Jobs, Not Welfare. Annandale-on-Hudson, NY: Levy Economics Institute, Bard College.

Nichols, Austin i Jesse Rothstein. 2016. „The Earned Income Tax Credit (EITC)”. W Economics of Means-Tested Income Transfers, red. Robert Moffitt. Cambridge: National Bureau of Economic Research, 137-218.

Painter, Anthony. 2016. „The age of insecurity is not coming. It's already here”. Royal Society of Arts blog, 2 maja.

Quigley, William P. 2003. Ending Poverty as We Know It: Guaranteeing a Right to a Job at a Living $W$ age. Philadelphia: Temple University Press.

Rawlinson, Kevin. 2014. „Thousands chased by HMRC debt collectors due to overpaid tax credits". Guardian, 30 maja.

Rothstein, Jesse. 2009. Is the EITC Equivalent to an NIT? Conditional Transfers and Tax Incidence. Washington: National Bureau of Economic Research, Working Paper No. 14966, maj.

Santens, Scott. 2016. „The progressive case for replacing the welfare state with basic income". TechCrunch, 9 września.

Standing, Guy. 1990. „The road to workfare: Alternative to welfare or threat to occupation?”. International Labour Review 129(6): 677-91.

Standing, Guy. 2015. „Karta Prekariatu”. Tłum. Piotr Juskowiak, Paweł Kaczmarski, Maciej Szlinder. Warszawa: PWN.

Standing, Guy. 2016. The Corruption of Capitalism: Why Rentiers Thrive and Work Does Not Pay. Londyn: Biteback.

Tanner, Michael i Charles Hughes. 2013. „The work versus welfare trade-off: 2013”, Cato Institute, cato.org, 19 sierpnia.

http://object.cato.org/sites/cato.org/files/pubs/pdf/the_work_versus_welfare_tradeoff_2013_wp.pdf.

Tanner, Michael. 2015. The Pros and Cons of a Guaranteed National Income. Washington: Cato Institute, p. 17.

The Economist. 2015. „Credit where taxes are due”. The Economist, 4 lipca.

The Economist. 2016. „Welfare reform: A patchy record at 20”. The Economist, 20 sierpnia: $11-12$.

Torry, Malcolm. 2016. Citizen's Basic Income: A Christian Social Policy. Londyn: Darton, Longman \& Todd. 
Guy Standing - angielski ekonomista, profesor studiów nad rozwojem w School of Oriental and African Studies na Uniwersytecie Londyńskim. Światową sławę przyniosły mu publikacje na temat prekariatu, zmian modeli zatrudnienia oraz kryzysu państwa dobrobytu. W latach 1975-2006 pracowal dla Międzynarodowej Organizacji Pracy, badając m.in. transformacje gospodarcze w krajach postkomunistycznych. Jeden z założycieli Basic Income Earth Network (BIEN). Opublikował m.in. Prekariat. Nowa niebeapieczna klasa (2011, wyd. pol. 2014), Karta prekariatu (2014, wyd. pol. 2015), The Corruption of Capitalism (2016), a ostatnio Basic Income, And How Can We Make It Happen (2017).

\section{DANE ADRESOWE:}

SOAS University of London

Thornhaugh Street

Russell Square

London WC1H OXG

United Kingdom

E-mail: guystanding@standingnet.com

CYTOWANIE: Standing, Guy. 2017. „Alternatywy dla dochodu podstawowego: przegląd krytyczny”. Tłum. Tomasz Płomiński, Praktyka Teoretyczna 2 (24): 15-38.

DOI: $10.14746 /$ prt.2017.2.1

\section{AUTHOR: Guy Standing}

TITLE: Alternatives to basic income: a critical review

ABSTRACT: A chapter of Guy Standing's book „Basic Income: And How Can We Make It Happen". The author analyses several policies aimed at dealing with economic crises, inequality and poverty: minimum wage, contributory social insurance, means-tested social assistance, subsidized food, tax credits, workfare and job guarantee. He evaluates those policies with regard to social justice principles and compares them with basic income.

KEYWORDS: basic income, job guarantee, social insurance, social justice, workfare 